\title{
Comparative Studies of National Business Cultures in the Countries of Central and Eastern Europe: the Basics for Improving International Entrepreneurship in Poland and Ukraine
}

\author{
Beata Glinkowska-Krauze \\ Ph.D., The University of Lodz, Faculty of Management, Lodz, Poland \\ e-mail: beata.glinkowska@uni.lodz.pl
}

legor Chebotarov

Ph.D., Luhansk Taras Shevchenko National University, Starobilsk, Ukraine

e-mail: iegor.chebotarov@gmail.com

\author{
Viacheslav Chebotarov \\ Doctor of Sciences, Professor, Luhansk Taras Shevchenko National University \\ Starobilsk, Ukraine, e-mail: vena.Inu@gmail.com
}

\begin{abstract}
Based on the work of Hofstede, Trompenaars, Lewis, and Rapaille, the founders of the theory of national business cultures and comparative economic studies, the characteristics of corresponding scientific areas are identified: cross-cultural management, cross-cultural communications, and cross-cultural marketing, including their methodological and practical aspects. Using the classic measuring parameters of national business cultures ("Individualism," "Power Distance," "Masculinity," "Uncertainty Avoidance," "Long-Term Orientation," "Indulgence"), a comparative analysis is carried out on the example of Poland, Ukraine, Germany, France, and Hungary; the results of the authors' own development of this interdisciplinary problem are presented. On this basis, new approaches are proposed in establishing mutually beneficial international cooperation between Polish and Ukrainian enterprises, not only in Europe but also in other regions of the world.
\end{abstract}


Keywords: comparative studies, national business culture, measuring parameters of national business cultures, management, communications, marketing, internationalization, Poland, Ukraine

JEL: O57, F23

\section{Introduction}

The analysis of economic facts and development trends of individual countries, gives grounds to note that modern management problems are largely predetermined by the nature and properties of the national business cultures of these countries. So far the problems of different national business cultures have not been sufficiently explored. The initial stage of issues related to national business cultures is typical of Ukraine and also of Poland. In the context of the entry into the European Union in this regard, Polish researchers presented a number of new and practical studies (Glinkowska, Kaczmarek 2016; Listwan, Stor 2008; Pocztowski 2002; Sitko-Lutek 2004).

This studies are particularly relevant to Ukraine. However, this is not fully recognized, either by the scientific community, business circles by the political establishment. Corresponding theoretical and applied developments (including those of a scientific and pedagogical nature) in Ukrainian economics are quite rare (Бондаренко ${ }^{1}$, Тодорова 2008; Glinkowska, Є. Чеботарьов, В. Чеботарьов 2018).

The first joint Polish-Ukrainian developments on this important both in the theoretical and practical aspects of the problem appeared (Glinkowska, Chebotarov 2018).

It should be noted that for Ukraine the problem of different national business cultures increases immeasurably in the context of the need to realize its high potential advantages in the system of the international division of labor and the practical problems of integration with the European Union.

The purpose of the article is to conduct a comparative study of national business cultures on the examples of Poland, Ukraine, Germany, France, and Hungary, and to substantiate the scientific and practical premises for the joint entry of Polish and Ukrainian business structures to the markets of Europe (and other regions of the world), that would be preceded by establishing effective forms of integrative cooperation.

The methodological basis of the research is formed by the works of Hofstede (1980a; 1994b; 2011c), Trompenaars (1993; Trompenaars, Woolliams 2003), Lewis (1999a; 2005b), and Rapaille (2004a; 2007b) the founders of the theory of national business cultures and modern economic comparativistics.

1 http://blogtrenera.ru/blog/pyat-kamnej-pretknoveniya-effektivnoj-kross-kulturnoj-kommunikacii. html (accessed: 20.08.2019). 
The basis of the research is the personal developments of the authors within the framework of the Center for Research and Scientific Cooperation: Poland-Ukraine ${ }^{2}$ (2016-2019), which is a detailed survey of managerial practitioners with in-depth interviews of business trainers, experts, analysts, andthe authorities of Poland, Ukraine, Germany, France, USA, and Spain. In addition, we used public materials from the Institute for Research on Intercultural Cooperation (IRIC, the Netherlands) and Hofstede Insights, the culture and strategy advisory and analytics organization which was establised by Geert Hofstede to cover the applicable aspects of his developments. ${ }^{3}$

The empirical basis of the research is our personal experience of entrepreneurial activity and the systematic analysis of theoretical and practical aspects of internationalization and globalization (Glinkowska 2018; Glinkowska, Kaczmarek 2016), as well as direct involvement in the implementation of projects of international charities from the USA, Germany, and Israel in Ukraine between 2015 and 2019 (Чеботарьов 2016; Чеботарьов, Колосов, Марков та ін. 2016).

The working hypothesis of the study - the national business culture reflects the system of phenomena, processes, and trends of economic, institutional and psychological nature, reproducible in space and time, characteristic of a certain country (or group of countries), which largely predetermine the formulation of goals, methods to achieve them, and the evaluation of the results of production and commercial activity of business entities and the functioning of non-profit organizations.

Research methods. In the context of modern epistemology, the methods that are most applicable in comparative economic studies were used: the grouping method (in identifying countries for comparing national business cultures); comparative analysis (in order to compare the characteristics of business cultures of a selected group of countries); the unity of induction and deduction (in the context of deriving the common characteristics of a given group of countries from the parameters of business cultures of individual countries and clarifying the relevant differences); and quantitative evaluation (for comparing the parameters of national business cultures).

\section{Presentation of the main material of the article}

There are three main areas in the study of the problems of national business cultures: managerial, communicative, and marketing, and studies in these areas have been carried out quite intensively. Therefore, the selected areas logically formed into relatively independent correspondent branches of knowledge, and then scientific (and also academic) disciplines.

2 http://zarzadzanie.uni.lodz.pl/Stronaglowna/Struktura/CentrumWsp\%C3\%B3\%C5\%82pracyBadawczoNaukowejPolskaUkrai/tabid/2704/Default.aspx (accessed: 20.08.2019).

3 https://www.hofstede-insights.com/about-us (accessed: 20.08.2019). 
The managerial approach to the study of national business cultures is embodied in cross-cultural management, the communicative approach in cross-cultural communications, and the marketing approach in cross-cultural marketing, respectively.

A generalized reflection of the comparative analysis of the aforementioned approaches is given in Table 1 (due to not only the largest representation of researchers of managerial aspects, but also to a significant contribution to the development of this problematics, the managerial approach was reviewed on the example of two authors, Hofstede, and Trompenaars).

"National Business Culture" is defined as a system of basic postulates and provisions of entrepreneurial activity that are inherent, formed over time, and reproducible in space and time; value motives and behavioral norms; rules, canons and traditions of entrepreneurial activity, as well as stereotypes, attributes, and business ethics of doing business in general which are peculiar to a particular country (or a group of countries that are close in their parameters).

The system of parameters of national business cultures used in modern economic comparativistics (mainly in comparative management) includes the following: "Individualism," "Power Distance," "Masculinity," "Uncertainty Avoidance," "Long Term Orientation," "Indulgence."

These characteristics were introduced by the Institute for Research on Intercultural Cooperation (IRIC) for the scientific and practical analysis of national business cultures, with a quantitative assessment for each meter-parameter is carried out by awarding scores that range from low to high. The IRIC was founded in 1973 by Geert Hofstede, who was its first director. This also implies the similarity of these measuring parameters to those proposed by Hofstede; however, there is a noticeable influence of the concept of Trompenaars.

The essential characteristics of national business cultures (meters-parameters) in the understanding of the IRIC and Hofstede Insights are as follows. ${ }^{4}$

"Power distance" is a parameter that defines the extent of the concentration of power at the highest hierarchical levels of management in organizations (enterprises, institutions, etc.) of certain types of business cultures of different countries. In countries with a big power distance gap, middle-level managers, and especially lower-level managers, have no real power. The inequality of people in the organization (and in society as a whole) and the presence of this kind of distribution of power are seen as natural phenomena.

"Individualism" classifies the degree of independence which is established and constantly reproduced by the organization and society (and the country as a whole). In countries with a high rate of individualism, members of the organization (and society as a whole) take care of themselves. By contrast, in collectivist societies, people who are members of organizations "belong" to them in a certain way.

"Masculinity" represents the degree to which success is cultivated and an independent career is developed, as well as the general level of competitiveness of the business

4 https://www.hofstede-insights.com/models/national-culture/ (accessed: 20.08.2019). 
environment of certain countries. The dominance of concern for the quality of one's life is classified as a sign of the femininity of the business culture as a whole. In countries with a high level of masculinity, people "live for work"; conflicts in organizations are usually resolved through struggle.

"Uncertainty avoidance" describes managers' desire to avoid uncertainty as such. Or vice versa - it is considered natural for business activities to be organized under conditions of uncertainty.

Table 1. Comparative analysis of methods and essential characteristics of approaches in the study of national business cultures

\begin{tabular}{|c|c|c|}
\hline $\begin{array}{l}\text { Approaches } \\
\text { and Authors }\end{array}$ & Methodical tools & Summary of the theory \\
\hline $\begin{array}{l}\text { Managerial } \\
\text { - Hofstede }\end{array}$ & $\begin{array}{l}\text { The selection of two-dimensional } \\
\text { meters of national business } \\
\text { cultures with their consideration } \\
\text { in the coordinate system } \\
\text { "Family - School - Work" and the } \\
\text { subsequent conducting of multiple } \\
\text { large-scale surveys (mainly on the } \\
\text { example of IBM). }\end{array}$ & $\begin{array}{l}\text { Characteristics of national business } \\
\text { cultures through the analysis of the } \\
\text { meters "Individualism - collectivism," } \\
\text { "Power distance," } \\
\text { "Masculinity - femininity," "Uncertainty } \\
\text { avoidance," "Confucian dynamism" } \\
\text { and the clustering of national business } \\
\text { cultures (for individual countries of the } \\
\text { world). }\end{array}$ \\
\hline $\begin{array}{l}\text { Managerial } \\
\text { - Trompenaars }\end{array}$ & $\begin{array}{l}\text { The selection of two-dimensional } \\
\text { meters of national business cultures } \\
\text { followed by a large-scale survey } \\
\text { (using the example of several leading } \\
\text { companies in the world). }\end{array}$ & $\begin{array}{l}\text { Characteristics of national business } \\
\text { cultures through the analysis of the } \\
\text { meters "Universalism - particularism," } \\
\text { "Individualism - communitarianism," } \\
\text { "Neutrality - emotionality," } \\
\text { "Specific - diffuse," } \\
\text { "Achievement - ascription," "External } \\
\text { control - internal control," "Sequential } \\
\text { time - synchronous time" and the } \\
\text { clustering of national business cultures } \\
\text { (by selected countries of the world). }\end{array}$ \\
\hline $\begin{array}{l}\text { Communicative } \\
\text { - Lewis }\end{array}$ & $\begin{array}{l}\text { The classification of two types } \\
\text { of behavior (introverts - extraverts) } \\
\text { and three-dimensional characteristics } \\
\text { of national business cultures (linear } \\
\text { activity, reactivity, multi activity) } \\
\text { followed by a large-scale survey (using } \\
\text { the example of a number of leading } \\
\text { companies in the world). }\end{array}$ & $\begin{array}{l}\text { The construction and description } \\
\text { of triangles with the placement on its } \\
\text { basis and the legs groups of } 2-4 \\
\text { countries with their identification } \\
\text { in the unity of the selected types } \\
\text { of behavior and characteristics } \\
\text { of national business cultures (for } \\
\text { individual countries of the world). }\end{array}$ \\
\hline $\begin{array}{l}\text { Marketing } \\
\text { - Rapaille }\end{array}$ & $\begin{array}{l}\text { The selection of the most typical } \\
\text { social strata in the frame of individual } \\
\text { countries and conducting research } \\
\text { using the focus group method } \\
\text { to understand the root causes of the } \\
\text { emotional state of consumers in the } \\
\text { assessment of consumer goods. }\end{array}$ & $\begin{array}{l}\text { Characteristics of national business } \\
\text { cultures through the disclosure } \\
\text { of the content of the triad "Logical } \\
\text { Emotionality" - "Archetype" - "Cultura } \\
\text { Code" and description of the cultural } \\
\text { codes of the leading countries of the } \\
\text { world. }\end{array}$ \\
\hline
\end{tabular}

Source: authors' own elaboration. 
"Long-term orientation" assesses approaches to the use of time in business activities, i.e., the ability of managers to distribute their actions within a short, medium, or long-term perspective. A high score of this parameter indicates the ability of executives to quickly adapt to changing conditions and the acceptance of investing in longterm business projects.

"Indulgence" represents the condescending attitude towards the absolutization of the market values of selfishness and profitability in business, as well as the spread of these values into all spheres of society. The opposite of indulgence is self-restraint, i.e., a certain reservation and moderation in achieving commercial success, which sets the social orientation of a business and a corresponding focus on the development of society as a whole.

For comparative studies of national business cultures, a set of countries consisting of Poland, Ukraine, Germany, France, and Hungary was chosen. The selection of Poland and Ukraine was naturally determined by the nationality of the authors. Germany and France are among the most developed countries of the European Union and possess advanced management schools. The choice of Hungary is dictated by the proximity of its conditions to the conditions of Poland and Ukraine, as well as its rich managerial culture.

Quantitative expressions of the parameters of national business cultures, as noted, are given according to the data from Hofstede Insights. ${ }^{5}$

Figure 1 provides an illustration of the characteristics of the national business cultures of the selected group of countries by the parameters "Power distance," "Individualism" and "Masculinity," with their respective quantitative expressions.

According to the "Power distance" parameter, the national business cultures of the analyzed countries are characterized by a high degree of difference. Germany's indicator for this parameter (35) is one of the lowest in the world. By contrast, Ukraine (92) is characterized by the highest indicator. This is one of the highest rates in the world (and is similar to the indicators typical for all countries of the former USSR). It is noteworthy that in this parameter, Poland's indicator directly corresponds to that of France (68).

The business cultures of the selected countries are characterized by the "Individualism" parameter. The highest score (80) belongs to Hungary, which is more than three times higher than the characteristics of Ukraine (25). The score of individualism in Poland (60) is approaching that of Germany (67). France is in the middle (71), between Poland and Hungary.

Note that the above scores of the "Individualism" parameter are an example of the assessment of national business cultures from the standpoint of Western management. From the standpoint of a Western specialist, a low indicator of this parameter is interpreted as a lack of entrepreneurship (Deresky 2000). By contrast, in Eastern management, high individualism is considered to be one of the most vulnerable components of entrepreneurship (Lee, Kuan Yew 2000).

5 https://www.hofstede-insights.com/country-comparison/ (accessed: 20.08.2019). 


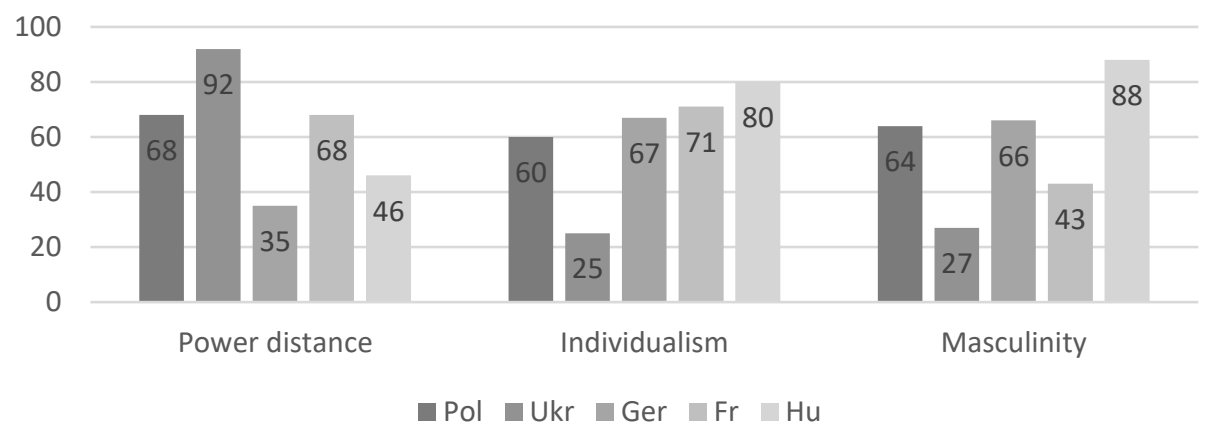

Figure 1. Comparative characteristics of the national business cultures of Poland, Ukraine, Germany, France, and Hungary of the "Power distance," "Individualism" and "Masculinity" parameters Source: https://www.hofstede-insights.com/country-comparison/poland,ukraine,germany,france,hungary/ (accessed: 20.08.2019).

The assessment of the parameter "Masculinity" is also not entirely unambiguous from the standpoint of Western and Eastern management. According to Hofstede Insights, Hungary's index (88) is more than three times higher than that of Ukraine (27); it serves as a classic example of feminine business culture. The indicators of Germany and Poland are very close (66 and 64, respectively). France (43) can also be classified as a country with a relative inclination towards the feminine business culture.

Based on our research, we cannot fully agree with the estimates of Hofstede Insights on cooperation on this parameter. In particular, we recorded a higher appreciation of the characteristics of masculinity in the business environment of Poland and Ukraine (along with the high skills of the managers in finding a balance of interests in business).

Figure 2 illustrates the characteristics and assessments of the national business cultures of Poland, Ukraine, Germany, France, and Hungary, presenting the other three parameters adopted in modern economic comparativistics in a similar way.

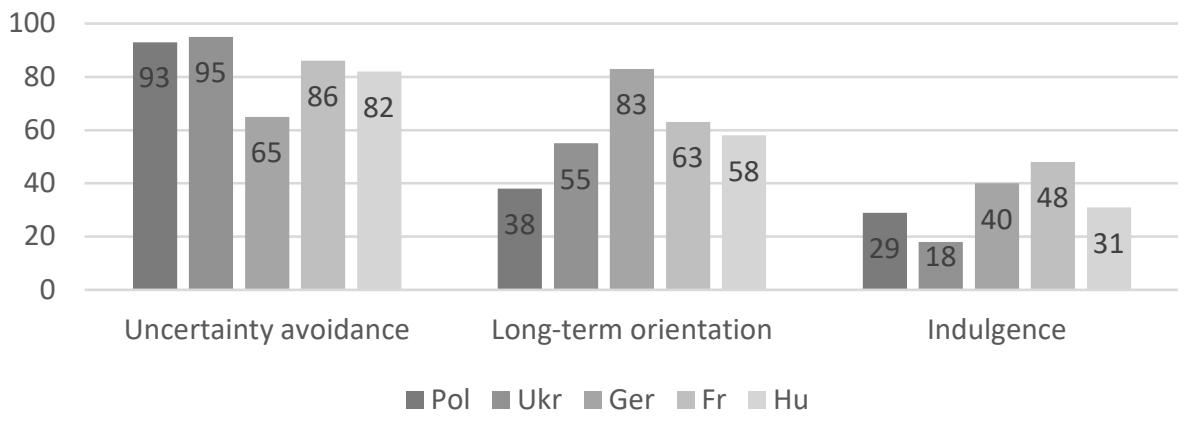

Figure 2. Comparative characteristics of the national business cultures of Poland, Ukraine, Germany, France and Hungary of the "Uncertainty avoidance," "Long-term orientation," and "Indulgence" parameters

Source: https://www.hofstede-insights.com/country-comparison/poland,ukraine,germany,france,hungary/ (accessed: 20.08.2019). 
Regarding the "Uncertainty avoidance" parameter, the countries are distinguished by a small range of scores. Ukraine and Poland are close in terms of their performance ( 95 and 93 respectively), while Hungary is close to France ( 82 and 86, respectively). Germany (65) is the most different. However, we note that a fairly high level of independence (and also creativity) was recorded for Ukrainian and Polish managers.

For the "Long-term orientation" parameter, the countries analyzed fall into three groups. Poland quite distinctly has a short-term orientation in business (its score is 38 ). Germany is a classic country with a long-term orientation (83). Hungary, France, and Ukraine occupy the middle and do not differ much from each other $(58,63$, and 55, respectively).

In terms of "Indulgence," the countries again fall into three groups. The most indulgent are France and Germany (their scores are 48 and 40, respectively). The scores of Hungary and Poland are very close (31 and 29). According to the estimates of Hofstede Insights, Ukraine's business culture (its score is 18) has the most pronounced characteristics of self-restraint and moderation in business.

However, our research does not confirm the high estimates for the social orientation of Ukrainian businesses. They showed that in modern conditions, its social orientation features have been largely lost. This is due, on the one hand, to the economic disability of the state as a supreme institutional entity, and on the other hand, to decades of rigid domination of the planned command economy and the suppression of every instance of entrepreneurship. The rich history of socially oriented business, in particular, the patronage movement in Ukraine (the dynasties of the largest entrepreneurs of that time, including Tereshchenko, Khanenko, Brodski, Alchevski) has yet to be revived.

The presented analysis of the national business cultures of Poland and Ukraine allows us to evaluate the course of their market reforms in a new way. More importantly, it allows us to substantiate the prospects, specific forms, and methods of their cooperation in world markets. With that, the following important considerations of institutional nature should be taken into account. Conducting a coordinated policy of Poland and Ukraine in the presence of sufficiently weighty natural and geographic, human, economic, investment, scientific and technical potentials gives all objective prerequisites to the economic entities of these two countries for the realization of effective and beneficial cooperation in the markets of goods and services not only in Europe, but in the whole world.

Our analysis allows us to state unequivocally that the national business culture of Poland fits the all-European business culture quite organically. It was, in many ways, a favorable basis for the success of market reforms in Poland in the late 1980s and early 1990s. In particular, it included implementing its European integration course, i.e., the relevant programs of the European Union (first, "Poland - Hungary: Assistance for the Reconstruction of the Economy," then "Instrument for Structural Policies for Pre-Accessions," and finally the sectoral programs), establishing cooperation with leading international organizations, and creating a favorable investment climate for foreign investors, among others. 
We confirm this with the results of our research. Poland's figure for the "Power distance" parameter in Fig. 1 corresponds to that of France. Regarding "Individualism" and "Masculinity," Poland's scores are close to those of Germany, while the score for "Indulgence" is very close to Hungary's.

Regarding Ukraine, the analysis allows us to note the following. The longer period of the domination of the socialist economy (as well as the peculiarities of the functioning of such an economy in Ukraine) had led to a significant decrease in entrepreneurial features in its business culture by the early 1990s. This was manifested in the maximization of the indicator "Power distance" parameter and a significant decrease in "Individualism." For this reason, market forms of economic management (especially with distance from the western borders) have hardly taken root in Ukraine. It is precisely because of the the years of the rigid socialist system and the low score for the indulgence parameter (which would seem strange in such a system) that favorable "institutional grounds" for corruption and bureaucracy formed in Ukraine. This is also the main brake for the market reforms today.

At the same time, the comparative analysis in the context of substantiating the prospects for the development of foreign economic activity provides theoretical grounds for the following comment. In terms of Poland's national business culture, "Individualism" and "Masculinity" will cause a number of subjective difficulties in conquering the markets in the Middle East, Central Asia, and also Southeast Asia and, partly, the countries of the Black Sea region (the so-called "eastern vector"). Our questionnaires and in-depth interviews with managers of Polish companies that have penetrated the markets of these regions provide practical proof of the validity of our comments.

At the same time, we note that, according to these parameters, Ukraine's indicators, in contrast to Poland's, correspond to a greater degree with the indicators of business cultures of the countries of the "eastern vector." Therefore, for the least costly and quickest way to overcome similar cross-cultural barriers, Polish business structures would be wise to attract Ukrainian managers.

For the same reasons, it would make sense for Polish enterprises to attract Ukrainian executives and entrepreneurs to adapt their norms and canons to the "Eastern management." Such adaptation by modern world management science is considered to be the optimal direction of development not only in the medium, but also in the long-term perspective.

Our studies confirmed the evaluation of the proximity of business cultures in Poland and Ukraine in terms of "Uncertainty avoidance" and "Indulgence." At the same time, unlike the specialists of the Institute for Research on Intercultural Cooperation and Hofstede Insights, we did not record any fundamental differences between the business cultures of Poland and Ukraine in the "Individualism" parameter. In fact, they revealed their similarity.

In the context of the characteristics of business culture, Ukraine, unlike Poland, is closer to the Pan-European median for the "Long-term orientation" parameter. On this basis, it would be considered reasonable for Polish entities to attract Ukrain- 
ian managers in order to more effectively advance to the markets of Western Europe, as well as the USA and Canada, in industries with a long production and commercial cycle, e.g., in the metallurgical, chemical, and mining industries, as well as in the implementation of large-scale infrastructure projects.

\section{Conclusions}

The problems of different national business cultures is a complex interdisciplinary problem. It covers all aspects of the economy (primarily, management and marketing), as well as a wide range of issues of a non-economic nature (e.g., the institutional sphere, communicative interaction, psychology, etc.).

The existing parameters of national business cultures in modern economic comparative studies are, in general, sufficient to reveal their characteristics. At the same time, the analysis of the business cultures of Poland, Ukraine, Germany, France, and Hungary indicated that the issues of understanding the general theoretical content of parameters with regard to the peculiarities of different countries are not sufficiently developed, e.g. the correspondence of parameters in business cultures of a number of countries; aspects of prognostic nature in the evolution of business cultures of individual countries (regions) and some others.

The analysis scientifically indicated that the national business cultures of Poland and Ukraine are not only close but also, to some extent, complementary to each other. This is a reliable basis for coordinating the economic policies of Poland and Ukraine, and implementing long-term mutually beneficial integration projects of business and public structures of these countries not only in Europe, but also in all other regions of the world.

\section{Prospects for the further development of the problem under analysis}

Future areas for research include deepening the content analysis of the parameters of national business cultures and undertaking a quantitative evaluation. Most importantly, future research should also investigate the corresponding linkages of these parameters in specific institutional and economic conditions applicable to specific countries and groups of countries.

At the same time, it is necessary to introduce appropriate components of sociology and innovations into the analysis, which would make it possible to investigate the problems of comparing national business cultures in the sphere of small and medium enterprises.

For Poland and Ukraine, the priority for further research into aspects of national business cultures is to explain the optimal forms of encouraging Polish and Ukrain- 
ian managers to implement joint activities in different regions of the world, taking into account industry characteristics and dimensional parameters of business in the context of diverse projects.

\section{References}

Deresky, H. (2000), International management: Management across borders and cultures, Upper Saddle River, NJ: Prentice-Hall.

Glinkowska, B. (2018), Internacjonalizacja polskich i ukraińskich przedsiębiorstw, Wydawnictwo Uniwersytetu Łódzkiego, Łódź.

Glinkowska, B., Chebotarov, V. (2018), A Comparative Cross-Cultural Analysis of the Profile of A Modern Ukrainian Manager: the Imperatives of the Future in the Context of Internationalization, "Comparative Economic Research Central and Eastern Europe” (1508-2008), Vol. 21, No. 3, pp. 63-74. https://doi.org/10.2478/cer-2018-0019

Glinkowska, B., Kaczmarek, B. (2016), Zarzadzanie międzynarodowe $i$ internacjonalizacja przedsiębiorstw. Teoria i praktyka, Wydawnictwo Uniwersytetu Łódzkiego, Łódź.

Hofstede, G. (1980), Culture's consequences: International differences in work-related values, Beverly Hills, CA: Sage Publications.

Hofstede, G. (1994), Culture and organizations: Intercultural cooperation and its importance for survival - software of the mind, HarperCollins, London.

Hofstede, G. (2011), Culture's consequences: Comparing values, behaviors, institutions and organizations across nations (second editions), Thousand Oaks: Sage Publications.

Lee, K. Y. (2000), From Third World to First: 1965-2000: Memoirs of Lee Kuan Yew, Vol. 2, Harper.

Lewis, R. (1999), Cross Cultural Communication: A Visual Approach, Transcreen Publications.

Lewis, R.D. (2005), When Cultures Collide: Managing successfully across cultures, $3^{\text {th }}$ ed. Nicholas Brealey Publishing.

Listwan, T., Stor, M. (red.) (2008), Zarzadzanie kadra menedżerska $w$ organizacjach międzynarodowych w Polsce, Wydawnictwo Uniwersytetu Ekonomicznego, Wrocław.

Pocztowski, A. (2002), Międzynarodowe zarządzanie zasobami ludzkimi, Oficyna Ekonomiczna, Kraków.

Rapaille, C. (2004), 7 Secrets of Marketing in a Multi-Cultural World., $2^{\text {nd }}$ ed. Tuxedo Production.

Rapaille, C. (2007), The Culture Code, Broadway Books.

Sitko-Lutek, A. (2004), Kulturowe uwarunkowania doskonalenia menedżerów, Wydawnictwo Uniwersytetu M. Curie-Skłodowskiej, Lublin.

Trompenaars, F. (1993), Riding the waves of culture: Understanding cultural diversity in business, Economist Books, London.

Trompenaars, F., Woolliams, P. (2003), Business across cultures, West Sussex: Capstone Publishing. 
Глінковська, Б., Чеботарьов, Є., Чеботарьов, В. (2018), Крос-культурні підприємницькі комунікації: навчально-методичний посібник для магістрантів, Держ. Закл, “Луган. нац. ун-т імені Тараса Шевченка”, Старобільськ.

Тодорова, Н. (2008), Крос-культурний менеджмент, ДонНТУ, Донецьк.

Чеботарьов, В.А. (2016), Чверть століття українсько-американської дружби: допомога Mercy Corps як модель міжнародної співпраці у подоланні наслідків військового конфлікту на Донбасі/ Агора. - Вип.16. - 2016. - С. 37-41.

Чеботарьов, В.А., Колосов, А.М., Марков, Р.В. та ін. (2016), - Основи бізнес-планування в мікро-підприємництві (наук.-практ. Довідник для бенефіціарів Mercy Corps) - Старобільськ: Д3. “Луган. нац. ун-т імені Тараса Шевченка”.

\section{Streszczenie}

\section{Badania porównawcze krajowych kultur biznesowych w krajach Europy Środkowej i Wschodniej: przesłanki poprawy międzynarodowej przedsiębiorczości}

Na podstawie badań i uogólnienia pracy twórców teorii narodowych kultur biznesu, a także na bazie ekonomicznych badań porównawczych przez G. Hofstede, F. Trompenaarsa, R. Lewisa i C. Rapaille, charakterystycznych dla odpowiednich dziedzin naukowych dokonano analizy takich zagadnień, jak: zarządzanie międzykulturowe, komunikacja międzykulturowa i marketing międzykulturowy - ich metodycznych i praktycznych aspektów. Korzystając z klasycznych parametrów pomiaru narodowych kultur biznesu („Indywidualizm”, „Dystans władzy”, „Męskość”, „Unikanie niepewności”, „Orientacja długoterminowa”, „Pobłażliwość”), przeprowadzana jest analiza porównawcza na przykładzie Polski, Ukrainy, Niemiec, Francji i Węgier; w opracowaniu przedstawiono wyniki badań własnego opracowania tego interdyscyplinarnego problemu. Na tej podstawie proponowane są nowe podejścia do nawiązywania wzajemnie korzystnej współpracy międzynarodowej między polskimi i ukraińskimi przedsiębiorstwami nie tylko w Europie, ale także w innych regionach świata.

Słowa kluczowe: badania porównawcze, narodowa kultura biznesowa, pomiar parametrów narodowych kultur biznesowych, zarządzanie, komunikacja, marketing, internacjonalizacja, Polska, Ukraina 